\title{
La revalorización del medievo en la estética masónica: Inglaterra y Escocia (siglos XIX y XX)
}

David Martín López

\section{(2) OpenEdition}

\section{Journals}

Edición electrónica

URL: http://journals.openedition.org/medievalista/287

DOI: $10.4000 /$ medievalista.287

ISSN: 1646-740X

Editor

Instituto de Estudos Medievais - FCSH-UNL

\section{Referencia electrónica}

David Martín López, « La revalorización del medievo en la estética masónica: Inglaterra y Escocia (siglos XIX y XX)», Medievalista [En línea], 15 | 2014, Publicado el 01 enero 2014, consultado el 10 diciembre 2020. URL : http://journals.openedition.org/medievalista/287 ; DOI : https://doi.org/ 10.4000/medievalista.287

\section{(c) $(1)(9$}

Mediavalista está licenciado com uma Licença Creative Commons - Atribuição-NãoComercial 4.0 Internacional. 


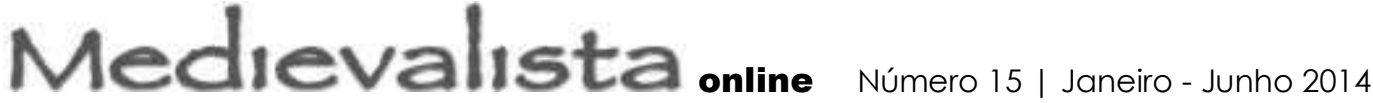

Título: La revalorización del medievo en la estética masónica: Inglaterra y Escocia (siglos XIX y XX)

Autor(es): David Martín López

Universidade: Universidad de Granada

Faculdade e Departamento / Unidade de Investigação: Departamento de Historia del Arte

Código Postal: 18071

Cidade: Granada

País: España

Contacto: dml@ugr.es

Fonte: Medievalista [Em linha]. №15, (Janeiro - Junho 2014). Dir. José Mattoso. Lisboa:

IEM.

Disponível em: http://www2.fcsh.unl.pt/iem/medievalista/

ISSN: $1646-740 \mathrm{X}$

Data recepção do artigo: 7 de Abril de 2013.

Data aceitação do artigo: 7 de Novembro de 2013.

\section{Resumo}

Este trabajo aborda, desde una perspectiva multidisciplinar, la temática del gusto por lo medieval en la masonería especulativa desde sus orígenes como grupo identitario con carácter supranacional, especialmente en Inglaterra y Escocia. La francmasonería, una de las primeras redes sociales contemporáneas surgida en los ambientes preilustrados ingleses (1717), dibuja un mapa global de corporativismo al más alto nivel -ya sea filantrópico, pedagógico, ético, moral e incluso político- desde los principios y valores estéticos asociados a las artes, principalmente a la arquitectura. 
Se genera así, dentro de la masonería, un debate identitario nacional de revalorización cultural de lo medieval en Europa, principalmente en Gran Bretaña donde masones como Walter Scott reivindican el gótico como el estilo verdadero.

Palavras-chave: Masonería, neogótico, arquitectura, estética, universalidad, identidad nacional.

\section{Abstract}

This essay reflects, from a multidisciplinary and holistic perspective, how the medievalism interacts with the aesthetics of Freemasonry from its origins to $20^{\text {th }}$ century, as a group with a supranational identity, principally in Great Britain -England and Scotland-. Freemasonry, considered as one of the first "social network", emerged in contemporary society of the pre-Enlightenment in England (1717), draw a global map of corporatism -whether philanthropic, educational, ethical, moral and even political senses could met there- with the principles and aesthetic values associated with arts and architecture. This aspects generates in Freemasonry, a national identity, a strong debate and revaluation of the Medieval culture in Europe, where freemasons as Walter Scott claimed the Gothic as the unique style.

Keywords: Freemasonry, Gothic revival, architecture, aesthetics, universalism, national identity. 


\section{La revalorización del medievo en la estética masónica: Inglaterra y Escocia (siglos XIX y XX)}

Da vid Martín López

\section{Introducción: El neogótico, gestación estética y herramienta masónica}

Cuando se tratan aspectos alusivos a la historia de la masonería especulativa, y por tanto coetánea al siglo XVIII, no resulta infrecuente en el imaginario colectivo, e incluso científico, remitir rápidamente a los gremios medievales como único modelo de su pasado. En verdad, la Orden del Gran Arquitecto del Universo, iniciada en Gran Bretaña en torno a 1717, y con sus constituciones formales desde 1723, obra de James Anderson y Teófilo Desaguliers, ahonda sus raíces en el carácter asociativo de la cultura británica del siglo XVIII, heredera directa de las viejas hermandades de canteros y operarios medievales, recuperada y en auge tras la reconstrucción de Londres a raíz del Gran Incendio de $1666^{1}$.

No obstante, en el siglo en que surge la masonería, el siglo de las Luces, las primeras manifestaciones simbólicas que se desarrollan en sus principales focos -Inglaterra, Escocia y Francia- renuncian a la perspectiva gótica de la que eran herederos simbólicos. Éstas son, ante todo, soluciones formalmente clasicistas que siguen parámetros estilísticos vitrubianos, acordes con sus cartas constitucionales.

\footnotetext{
1 Trabajo de investigación desarrollado durante dos estancias de investigación oficiales dentro del programa FPU del Ministerio de Educación español realizadas en Gran Bretaña: University of Central Lancashire (Preston, 2007) y Leeds Metropolitan University (Leeds, 2008).
} 
Es decir, pese a que la propia masonería sintiese esa vocación gremial del gótico anhela, en primera instancia, ese humanismo renacentista que pervive reposado en el clasicismo británico cuyas invariantes habían perdurado a los estilos imperantes. Esta circunstancia se explica a través de la modernidad que suponía la masonería filosófica -que entroncará más tarde, y en muchos sentidos, con las ideas de la Ilustración-. De esta forma, la arquitectura medieval británica no sólo fue denostada por sus miembros, sino que además, el antitético clasicismo se convirtió en el único modelo estético factible, llegando a ser, incluso, oficializado por la masonería. Es decir, el clasicismo arquitectónico es empleado a modo de estilo institucional de la francmasonería hasta finales del siglo XVIII, perdurando en algunas regiones hasta fines del siglo XIX. Resulta significativo que, incluso, el gran arquitecto del neogótico Thomas Barry, autor del Parlamento británico, cuando proyectara la logia del Eastern Hotel de Liverpool Street, la hiciera con un estilo clasicista en vez de neogótico.

Esta cuestión es de una especial relevancia, pues las mismas Constituciones de Anderson $(1723)^{2}$ se pronunciaban en contra del Gótico como estilo propio de una época oscura de barbarie e ignorancia. Las Constituciones consideran, al respecto, que el rey James VI de Escocia y I de Inglaterra, como si de un humanista redentor se tratara, fue quien salvó a su pueblo de la ignominia mediante la Geometría y la apuesta clara por el Renacimiento.

Estas Constituciones, que formalmente tienen una finalidad cuasi hagiográfica, plantean un panteón francmasónico desde el origen de los tiempos, efectuando todo un panegírico de la historia masónica universal, hasta llegar a la Inglaterra de la Gran Logia, que, incluso, incluye a Adán y Eva. Cuando trata el gótico, Anderson lo hace, en todo momento, de una forma totalmente despectiva. Tiene una razón contextual importante, tanto geográfica como histórica, pues en naciones como Inglaterra o Escocia, los valores góticos habían coexistido con postulados modernos durante varias centurias que van desde el siglo XVI hasta pleno siglo XVIII. El gótico actuaba por estas fechas y en estos lugares todavía como solución técnica e inconscientemente se

\footnotetext{
${ }^{2}$ Cfr. ANDERSON, James - Constitutions of Free-masons. Pensilvania: Benjamín Franklin ed., 1734.
} 
estimaba como forma retardataria -útil y bella- a nivel constructivo, y así dialogaba con la modernidad contemporánea: ya fuera renacentista, barroca o clasicista.

Por tanto, si la masonería filosófica del siglo XVIII pretendía ser moderna como quiere y afirman sus premisas, inicialmente debía alejarse de toda alusión gótica y medieval. Incluso, comprendiendo el verdadero uso y cuidado de los escoceses en la verdadera masonería, es decir, la operativa; las Constituciones denominaban al Gótico como la etapa de la ignorancia, época que había salvado el rey James VI, tras el reinado de la reina Isabel I, que no pudiendo ser masona no hizo nada por proteger y promover este arte real. La misoginia de Anderson hacia la reina ${ }^{3}$, así como la misoginia inicial de la masonería, se entrelazan junto a estas ideas del Gótico en los capítulos de las Constituciones:

Yet the great Care that the SCOTS took of true Masonry, prov'd afterwards very useful to ENGLAND; for the learned and magnanimous Queen ELIZABETH, who encourag'd other Arts, discourag'd this ; because, being a Woman, she could not be made a Mason, tho' as other great Women, she might have much employ'd Masons, like Semiramis and Artemisia. But upon her Demise, King JAMES VI of SCOTLAND succeeding to the Crown of ENGLAND, being a Mason King, reviv'd the English Lodges ; and as he was the First King of GREAT BRITAIN, he was also the First Prince in the World that recover'd the Roman Architecture from the Ruins of Gothic Ignorance ${ }^{4}$.

Con la llegada del romanticismo, el debate interno de la francmasonería, suscitado en el interior de las logias sobre qué modelos estilísticos adoptar, es eminentemente europeo, y no acontece de la misma forma en otras naciones, libres de las trabas culturales

\footnotetext{
${ }^{3}$ Es curioso cómo indica Anderson que la reina Isabel I no quiso continuar con la reunión anual de masones en Escocia por miedo a una rebelión subversiva y conspirativa contra el gobierno. Miedos, que la Orden tuvo que enfrentar también en el siglo XVIII y XIX, por lo que la nota al pie que se realiza en las Constituciones no era anacrónica.

${ }^{4}$ Cfr. ANDERSON, James - op. cit., p. 35.
} 
historicistas. En el resto de continentes donde la masonería tiene presencia, la lógica ausencia de un pasado medieval histórico los exime de toda responsabilidad y juicio a la hora de valorar cómo debe ser una logia en estos términos, permitiéndose licencias inexplicables en contextos europeos. Sobre todo, este problema tiene su fundamento en Gran Bretaña, e indirectamente en Italia, Bélgica, Alemania, Portugal y España, naciones donde el pasado medieval es importante en su historia y patrimonio ${ }^{5}$.

A principios del siglo XIX, la gran parte de las Obediencias existentes tenían un carácter monoteísta en sus creencias, considerando al Gran Arquitecto del Universo como Dios, una especie de Padre Creador, que entroncaba directamente con las percepciones medievales. El carácter simbólico del espacio sagrado en la Edad Media, principalmente la construcción de sus catedrales, despertará en las sociedades masónicas anglosajonas una inusitada pasión durante el siglo XIX y las primeras décadas del siglo XX.

Como muchos historiadores han apuntado, fruto del desencanto de la sociedad tardobarroca e ilustrada, nace una especie de sentimiento nacional, de identidad propia en la mayor parte de cortes europeas, que lleva implícita una reivindicación política y cultural preconizadora de los valores románticos. La identidad de los pueblos centroeuropeos y anglosajones empieza a ser analizada desde una perspectiva romántica, mítica y legendaria, buscando los parámetros primigenios de una conducta clara de estilo nacional donde ahondar sus estudios, fijar sus principios y anhelar unas posibles pautas de futuro a través del nuevo estilo o lenguaje basado en las glorias de su Edad Media. Es ahí donde precisamente deciden sentar las bases estéticas y teóricas del territorio.

Este primer Romanticismo, en opinión de David F. Ash, es un renacimiento de lo medieval, "abortivo en tanto en cuanto prematuro"6. Sin embargo, debemos subrayar que el historicismo, principalmente el neogótico propuesto, será una de las soluciones a

\footnotetext{
${ }^{5}$ A raíz de la negación oficial en 1877 de Dios como Gran Arquitecto del Universo por parte del Gran Oriente de Francia no podemos inducir a error al lector con una valoración similar en el contexto francés. ${ }^{6}$ ASH, David F. - "Creative Romanticism". In College English. Chicago. ISSN: 0010-0994. vol. 4, núm. 2 (1942), pp. 100-110.
} 
la búsqueda de la representación nacional, de una unidad estilística bajo la que configurar un corpus estético nuevo.

En las primeras décadas del siglo XVIII, muchos comitentes masones, tras realizar el Grand Tour y una estancia larga en Italia $^{7}$, preferían las adaptaciones del arquitecto escocés Colin Campbell (1676-1729) ${ }^{8}$, basadas en los valores clásicos de Palladio. Lord Burlington con Chiswick House (1729), abriría una veda clasicista neopaladina a muchos otros comitentes aficionados a las artes y primigenios francmasones como Thomas Coke, I Earl of Leicester, con su Holkham Hall y Charles Lennox, II Duque de Richmond con su Goodwood House., también aparecían desde la propia Orden posicionamientos favorables al gótico -a la recreación historicista y no necesariamente pintoresquista de Strawberry Hill (1749-1753) ${ }^{9}$ o de la novela gótica El Castillo de Otranto (1764) de Horace Walpole-. A finales del siglo XVIII, lo medieval sería reivindicado desde múltiples facetas en la cultura europea, incluso en los círculos masónicos que habían asumido y aceptado el nuevo clasicismo ${ }^{10}$.

Es por ello que, mientras las posiciones oficiales de la masonería abogaban por adoptar un orden clásico rígidamente grecorromano, algunas de las personalidades que se encuentran en el proceso transicional desde la masonería operativa a la especulativa como Batty Langley (1696-1751), fueron elementos disidentes del sentir andersoniano, ya que como conocedores del pasado patrimonial de la herencia gremial británica no podían denostar el Gótico.

La devoción masónica de Langley trasciende el ámbito de la praxis arquitectónica, del diseño de jardines y de la teorización, pues lo lleva a bautizar, a cuatro de sus catorce

\footnotetext{
${ }^{7}$ Caso significativo es el encuentro en 1715 por tierras italianas de William Kent, Lord Burlington y Thomas Coke.

8 Editó tres volúmenes (1715, 1717 y 1725), de lo que se denominó Vitruvius Britannicus, donde teorizaba sobre los edificios clásicos contemporáneos en Gran Bretaña.

${ }^{9}$ En este sentido, Horace Walpole relata la idea de edificar un pequeño castillo gótico en 1749. Exista una segunda fase de 1760 a 1772 y otra tercera fase constructiva en 1776 que aborda el arquitecto masón James Essex.

${ }^{10} \mathrm{El}$ empleo de las ruinas góticas (neogóticas) realizadas ex profeso, de los edificios neogóticos insertos en ejemplos significativos como Wörlitz, son planteados como soluciones de diálogo y apertura hacia las nuevas ideas románticas dentro de un mundo clasicista. Cfr. CURL, James Stevens - "Arkadia, Poland: Garden of Allusions". In Journal of Garden History. Londres. ISSN: 0144-5170. Vol. 23, núm. 1, (1995). The Garden History Society, pp. 91-112 y cfr. ALEX, Reinhard y KÜHN, Peter - Schlösser und Gärten um Wörlitz. Leipzig: VEB.E.A. Seemann Buch und Kunstverlag, 1988. ISBN: 3-363-00366-8.
} 
hijos, con los simbólicos nombres de Vitrubio, Euclides, Hiram ${ }^{11}$ y Arquímedes ${ }^{12}$. Sus publicaciones Ancient Architecture (1734) y Ancient Masonry (1733-1736), junto con The Builder's jewel (1741) [1], como comentan algunos biógrafos, suponía una forma de poder alimentar a sus hijos, debido a que este tipo de publicaciones tenían una gran recepción en los constructores, canteros y arquitectos. Además, gracias a la masonería, vigente como red, su difusión era si cabe aún mayor ${ }^{13}$. Los constructores y artesanos anhelaban contar con una serie de recetarios que solventaran la manera de enfrentarse ante la erección de un edificio. Su primera publicación llevaba por título Ancient Architecture, Restored and Improved by Great Variety of Grand and Useful Designs, entirely new in the Gothic Mode... Se proponía un nuevo modo de Gótico: una forma gótica-clásica. Por ello, una nueva reedición de 1747 se denominó simplemente Gothic Architecture $^{14}$. Curiosamente, las publicaciones de Langley que levantaron polémica entre algunas personalidades como Horace Walpole -que denominó estas propuestas como Bastard Gothic- están respaldadas por logias y francmasones notables como el duque de Lorena, primer miembro de la familia real que llega a ser Gran Maestro de la masonería inglesa.

That work was Ancient Masonry, a giant compilation of the works of other architects, published in parts from 1733 to 1736 for the use of builders, in accordance with Hiram's commands, and dedicated to the most distinguished noble Grand Masters headed by Francis, Duke of Lorrain, the first royal freemason, installed in 1731. The Builder's Complete Assistant of 1738 (also published as The Builder's Compleat Chest-Book) was subscribed to by the Sun Lodge of St Paul's Church-Yard, Talbot Lodge of Stourbridge, and by hundreds of craftsmen who received, with their seventy-seven illustrations of the orders

\footnotetext{
${ }^{11}$ Hiram Abiff es arquitecto del Templo de Jerusalén en el que se basa la francmasonería.

12 Cfr. HARRIS, Eileen - "Batty Langley: A Tutor to Freemasons (1696-1751)". In The Burlington Magazine. Londres. ISNN: 0007-6287. Vol. 119, núm. 890, Mayo (1977).

${ }^{13}$ ROWAN, Alistair - "Batty Langley's Gothic". In Studies in Memory of David Talbot Rice. Edimburgo: Edinburgh University Press, 1975, p. 210. ISBN: 9780852242537.

${ }^{14}$ HERNÁNDEZ GUTIÉRREZ, Sebastián - La estética masónica. Arte e historia de los más afamados protagonistas de la masonería internacional. Santa Cruz de Tenerife: Graficolor, 1998, pp. 57-59. ISBN: 9788489692138.
} 
and related ornaments, a 'legendary history of geometry more or less as it appears in typical MSS. Constitutions of Masonry' ${ }^{15}$.

Ancient architecture es una declaración de principios para la exaltación del Gótico, como estilo sobresaliente, con una supremacía artística que hasta le permite dialogar con otros estilos clásicos, y pudiendo componer edificios dórico-góticos o jónicogóticos.

Si bien no era la tónica habitual en los arquitectos y teóricos de principios del siglo XVIII en Italia, también Guarino Guarini había señalado cuestiones similares en su Archittetura Civile (1737). Para los hermanos Thomas y Batty Langley el valor ornamental orgánico de la arquitectura medieval podía ser aplicado a los rígidos cánones de la tradición grecolatina. La defensa a ultranza del Gótico junto a lo clásico, se relaciona con un esfuerzo ideológico profundamente masónico que magnificara los gremios de canteros asemejándolos a aquellos que habían realizado el Partenón. Recuérdese aquí la idea de Schinkel, con aquellas visiones utópicas de la Grecia clásica en la que masones operarios, casi gremiales, trasladaban las piezas de cantería como si de la construcción de una gran catedral se tratara.

Esto no es óbice para que en gran parte de sus proyectos no realizados -paralelos a los de impronta clasicista-, fueran bocetos y lienzos pictóricos donde aparecía la exaltación del gótico dentro de la idea de identidad nacional alemana. Las grandes catedrales anheladas por Luis II de Baviera en su diario con alusiones templarias filomasónicas ${ }^{16}$, ya fuere por deseo expreso del artista o de los comitentes, pueden observarse en el Kreuzberg (1821-1816) u otras formulaciones de arquitecto francmasón K. F. Schinkel, como el.

\footnotetext{
${ }^{15}$ HARRIS, Eileen - op. cit.

${ }^{16}$ Las excentricidades del rey Luis II, obsesionado por el rey Arturo, las leyendas teutónicas y el Santo Grial lo llevan a la masonería, originando posteriormente un nuevo discurso de la misma en sociedades paramasónicas totalmente diferentes en forma y finalidad. Cfr. nominación de las logias a las que pertenecía el rey en CZUDNOCHOWSKI, Biegon von - Handbuch für Freimaurer: ueber den Urpsrung und die Geschicte des Ordens. Neuwied, 1862, p. 178.
} 
H. M. Colvin, en 1948, aclara que no debemos confundir en Gran Bretaña estas supervivencias del Gótico con la identidad del revival ${ }^{17}$ primigenio, que derivó más tarde en las teorizaciones del Gothic revival de W. A. Pugin (1812-1852), entre otros arquitectos historicistas y eclécticos. La masonería adopta lo gótico como una herramienta simbólica y ética, revalorizando así, en un sentido estético y espiritual, ciertos valores perdidos en la sociedad, lo que imprime un marcado carácter prerromántico. El Gótico sirve ahora de inspiración poética a masones como Sir Walter Scott (1771-1832) o Goethe (1749-1832) ${ }^{18}$, quienes dedican poemas y ensayos a paradigmas masónicos -en sentido operativo -como Melrose Abbey y la Capilla de Rosslyn $^{19}$ (Escocia) o la Catedral de Estrasburgo ${ }^{20}$, respectivamente. Todo ello muestra el complejo caldo de cultivo en el que germinarán las tendencias más representativas de los movimientos medievales europeos, llegando estos a convertirse en los estilos arquitectónicos por excelencia del futuro siglo XIX.

En Escocia, se refuerza la identidad nacional a través del análisis, estudio y revalorización de la ruina gótica como motivo de inspiración arquitectónica y poética. La abadía cisterciense de Melrose, donde muchos nobles y reyes escoceses como Alexander II habían sido enterrados, se convierte en centro de peregrinación masónica, al igual que Rosslyn Chapel. La piedra filosofal del matemático medieval Michael Scot creía haberse encontrado en 1812 en esta abadía. Esta leyenda se añadía a la de John Morvo, maestro masón operativo escocés y constructor de la misma abadía de Melrose. A principios del siglo XIX este ya era un personaje reivindicado como nombre simbólico en la masonería especulativ y se le considera como autor de una inscripción

${ }^{17}$ COLVIN, H. M. - "Gothic Survival and Gothic Revival”. In Architectural Review. Londres. ISSN: ISSN: 0003-861X. CIII (1948), pp. 91-98.

${ }^{18}$ Determinadas cuestiones relativas a la percepción del gótico, tienen un trasfondo masónico en Goethe, en obras realizadas tras estancia en Estrasburgo en el invierno de 1770-1771, coincidiendo con en la ciudad con Herder, también francmasón. Para el análisis masónico en Goethe cfr. BOYLE, Nicholas Goethe, the poet and the age, vols. I, II y III. Bath, Bookcfraft, 1992. ISBN: 0-19-282981-5. No obstante, debemos señalar que Goethe no será adepto masón hasta 1781.

19 SCOTT, Walter - The Lay of the Last Minstrel, A poem in six cantos. Nueva York, 1844. Canto Segundo, XXIV, pp. 89-90. Comenzado en 1802 y publicado en 1805, es un poema que aborda las tradiciones legendarias de las zonas fronterizas de Escocia, introduciendo aspectos mágicos del poder sobrenatural del Gótico. OLIVER, Susan - "The Lay of the Last Minstrel”. In The Literary Encyclopedia. ISSN: 1747-678X (2005). http://www.litencyc.com/php/sworks.php?rec=true\&UID=384 [consultado el 10 febrero de 2013].

${ }^{20} \mathrm{Su}$ obra Sobre la arquitectura alemana (1773) posee un himno en prosa dedicado al arquitecto de la catedral de Estrasburgo. 
hallada en una de las escaleras del complejo monacal con la siguiente expresión: "Be halde to ye hende", que significa "Keep in mind, the end, your salvation"21, convirtiéndose posteriormente en el lema de la propia población del Melrose. La abadía se convirtió en un motivo recurrente entre los masones escoceses y extranjeros, hasta el punto que fue reproducida por David Roberts o Louis Daguerre, además de elogiada en poemas por Walter Scott.

En esta misma línea, y a modo de preámbulo del romanticismo, podemos señalar las extraordinarias mitografías masónicas del artista y teórico de la arquitectura británica Joseph Gandy (1771-1843). En ejemplos como Comparative Architecture, an emblematic sketch (1837), se aprecia su interés por el sincretismo religioso desde una perspectiva utópica $^{22}$, apareciendo casi siempre lo gótico, en esta ocasión gótico belga, como cerramiento del templo ideal. Curiosamente, cuando Gandy efectuaba determinadas proyecciones arquitectónicas, buscaba fórmulas comedidas, sobrias y clásicas que bien podrían ser similares a obras racionalizadas de John Nash.

Las leyendas de Merlín y su tumba fueron reivindicabas por la masonería británica desde el siglo XVIII. De acuerdo con Ariosto, Merlín "El Mago" había sido impresionado y asesinado por la Bruja del Lago, quien le robaría sus poderes mágicos. El cuerpo y el espíritu de Merlín fueron lo último en permanecer con vida según el poeta, y se mantuvieron dentro de un arcón de piedra dura, brillante -pues iluminaba toda la cueva- y pulida, como si fuera una rosa ${ }^{23}$.

Esta leyenda, tamizada a través de la Orden, conectada ahora con la tumba de Hiram, con la irrupción del mal sobre el bien, por lo que incluso la rosa en contraposición a la acacia hiramita cobraba un doble significado para iniciados como Gandy a la hora de revalorizar el poemario con tintes románticos.

\footnotetext{
21 "Recuerda, el final, tu salvación".

${ }^{22}$ LUCKACHER, Brian - "Joseph Gandy and the Mythography of Architecture". In The Journal of the Society of Architectural Historians. California. ISSN: 0037-9808. Vol. 53, núm. 3 (1994), pp. 280-299 e LUCKACHER, Brian - Joseph Gandy: and architectural visionary in Georgian England. Londres: Thames \& Hudson, 2006. ISBN: 9780500342213.

${ }^{23}$ MAGGI, Angelo - "Poetic Stones: Roslin Chapel in Gandy's Sketchbook and Daguerre's Diorama". In Architectural History. Londres. ISSN: 0066-622X.Vol. 42 (1999), p. 280.
} 
Gandy representa la Tumba de Merlín (1815) como si de una especie de Rosslyn Chapel se tratara, y dibuja, incluso, el emblemático Pilar del aprendiz. De hecho los bocetos y estudios exhaustivos que Gandy hace en la capilla de Rosslyn a principios del siglo XIX, le sirven ahora para esta composición fantástica, con una escala utópica que confiere al espacio un halo misterioso. Se aprecia la presencia de un personaje diminuto, arrodillado ante el altar del Cristo crucificado, que da la referencia real de las proporciones del conjunto, por lo que, el sarcófago-arca donde se encuentra Merlín se convierte en un gigantesco monumento bizantino, híbrido estético de los sarcófagos de plata y piedras preciosas de los centros de peregrinación del Medievo. Con brillo refulgente, sobrenatural, el sepulcro ilumina todo el espacio en la línea de la versión poética anglosajona del Orlando de John Harrigton (1634). Su luz, como si se tratara de la luz masónica, encierra los secretos del bien y la verdad espiritual ${ }^{24}$.

Los francmasones inician así un peregrinar historiográfico y personal, científico y mitológico, a la búsqueda de orígenes y presencias alquímicas o masónicas en toda Europa. Intentan estudiar, decodificar las claves de la piedra filosofal, valorar y conocer aquellas marcas de cantería que los masones operativos dejaran en la Edad Media tanto en castillos como en catedrales. Éstas han sido siempre elementos simbólicos empleados por la masonería especulativa. Por ello, estos signos y las herramientas de los constructores gremiales serán elementos de especial relevancia en los rituales masónicos.

El compás, la escuadra -normalmente de proporción áurea-, la plomada, la pala, el pico, la hoz, la azada, el cincel, el martillo, mazo, mollete, la regla de 24 pulgadas, el nivel, la palanca y otras herramientas son una buena muestra de ello. Dentro de estos elementos gremiales, tres de ellos representan las Joyas Móviles de la Logia masónica ${ }^{25}$. Estas joyas " [...] moralmente sirven: la escuadra para indicarnos que nuestras acciones deben

\footnotetext{
${ }^{24} \mathrm{Al}$ analizar determinadas arquitecturas funerarias masónicas, la idea de la luz estará muy presente. La composición además de ser rematada en piedra o mármol blanco, puede incorporar a ella elementos lumínicos como plafones o lámparas doradas para crear el misterio de Merlín.

${ }^{25}$ DESANTES FERNÁNDEZ, Blanca y FRADES MORERA, Ma José - Atributos masónicos en el Archivo Histórico Nacional, Sección Guerra Civil. Salamanca: Archivo Histórico Nacional, Sección Guerra Civil de Salamanca, 1993. p. 44. ISBN: 9788477970873.
} 
ser justas, el nivel que ha de reinar una igualdad perfecta entre los masones, y la plomada, que todo bien procede de lo alto"26.

Las logias británicas recuperan para sus "tenidas" viejos espacios góticos, iglesias neogóticas desacralizadas o lugares que crean bajo pautas neogóticas para la tipología de la Orden. Tal es el caso de la Philanthropic Lodge en Leeds. Este templo masónico neogótico para la institución homónima, obra de Perkin \& Sons, fue construido a espaldas del Ayuntamiento y conserva, en la actualidad, todos los elementos gremiales en fachada, ubicados en dos tondos. El tondo central presenta el ojo de Dios que todo lo ve inserto en una estrella de seis puntas formada por dos triángulos invertidos [2]. En el interior de la logia existió una bóveda celestial pintada de azul que reforzaba las ideas medievales francmasónicas.

En Estados Unidos, no obstante, las logias construidas ex profeso como tales, antes de finales del siglo XIX son libres de elegir su estilo. El país no tiene una tradición gótica, aunque sí palladiana, que le influya en las decisiones estilísticas; por lo que, incluso hasta mediados del siglo XIX, puede ser tan habitual la construcción de una logia románica como gótica, como la paradigmática neorrománica Gran Logia de Filadelfia de J. H. Widrin (1868) ${ }^{27}$ o el Masonic Gothic Hall (1830) [4].

Los acercamientos del Románico con la francmasonería en Europa son escasos y se producen en zonas como Cataluña y Alemania, cuya trascendencia y desarrollo medieval en la época fue notable. Por el contrario, en fechas semejantes, en Gran Bretaña un templo masónico, de no ser neogótico preferirá serlo neogipcio, antes que neorrománico por principios identitarios.

Dentro de esta revalorización medieval en el arte masónico, las formulaciones neogóticas trascienden el ámbito de la logia. Y es que, aunque el centro de las actividades mensuales de la logia sea el templo masónico, también es verdad que existen ocasiones en los que el peso importante de los comitentes masones activos en la vida política, cultural y económica de una ciudad, principalmente en Inglaterra y

\footnotetext{
${ }^{26}$ AAVV - Diccionario del Gran Oriente de Francia. Barcelona: Ediciones Obelisco, 2002, p.56. ISBN: 9788477208976.

${ }^{27}$ MEEKS, Carroll L. V. - "Romanesque before Richardson in the United States". In The Art Bulletin, vol. 35, núm. 1, 1953, p. 17.
} 
Escocia, determina que se realicen algunos edificios con referentes de la estética masónica en los que las pautas góticas siguen presentes.

Este sería el caso del nuevo Ayuntamiento de Maybole (1887) [3], Escocia, cuya primera piedra fue cimentada en una tradicional ceremonia masónica bajo la dirección de Sir James Fergusson ${ }^{28}$, escogiendo obviamente, y no de forma arbitraria, el Gothic revival con carácter escocés, el denominado Baronial style teorizado principalmente por David Bryce, arquitecto masón destacado en Edimburgo.

Debido a las reminiscencias gremiales de la masonería especulativa, en determinados monumentos conmemorativos a personalidades francmasónicas, también se optó por el neogótico, imprimiéndose ocasionalmente un doble significado masónico: el de la exaltación nacional y el de la Orden.

El ejemplo más significativo que podemos resaltar es el Monumento a Sir Walter Scott en Edimburgo [6]. En 1836 se establece una competición para elegir el proyecto de monumento arquitectónico al poeta, activo francmasón y padre de la identidad nacional escocesa, percibido ya en estas fechas como tal.

El estilo exigido en el concurso, como sucedió en otro británico de similares características en 1903, debía ser neogótico según las líneas marcadas habitualmente ${ }^{29}$. Los concursantes participarían con un nombre no reconocible, para así mantener su anonimato. El proyecto ganador fue el del dibujante autodidacta y masón escocés George Meikle Kemp (1795-1844), presentado con el seudónimo del cantero John Morvo, ya referido anteriormente por la construcción de Melrose Abbey [5].

Kemp, al no ser arquitecto titulado, tuvo que adaptar su diseño, tras una enorme controversia sobre las competencias y viabilidad proyectual de la obra. El dibujante escocés había convencido al comité para que la cimentación del megalómano monumento se hiciera a gran profundidad, debido a la considerable altura del conjunto y

\footnotetext{
${ }^{28} \mathrm{http}: / /$ www.maybole.org/history/archives/masons/layingthestone1.gif. [acceso $10 \mathrm{de}$ febrero de 2013].

${ }^{29}$ Nos referimos a la Catedral de Liverpool que por su importancia dentro del ámbito del anglicanismo internacional también se ejecutó bajo pautas estéticas neogóticas.
} 
a que miembros de la Caledonian Railway Company $^{30}$ habían propuesto excavar un túnel debajo de Princess Street -calle anexa al monumento- a unos ocho pies (2’6 m.) de la fundación del hito. George Meikle Kemp, entonces, invitó a varios amigos para que atestiguaran con él la colocación "real" de la primera piedra; si bien el 15 de agosto de 1840 se atendió a la ceremonia oficial de la tradicional y masónica Laying of the Foundation Stone por los masones de la Gran Logia de Escocia. Encabezados por Sir James Forrest de Comiston, Gran Maestro de Escocia y en ese momento Lord Prevost ${ }^{31}$ de Edimburgo, y George Pearson de la Logia de San Juan, la comitiva partió desde el patio de honor de la Universidad de Edimburgo hasta el monumento, llevando el preceptivo traje negro, guantes blancos, mandil y las joyas masónicas de grado, asumiendo así el papel importante en la construcción del mismo por deseo del propio ganador $^{32}$.

Tras un fatídico accidente en marzo de 1844, Kemp fallece, por lo que le sucede en la inmensa fábrica su cuñado, el pintor William Bonnar (1800-1853) quien lo había retratado en 1844. El 17 de agosto de 1846, finalmente el monumento es inaugurado por Adam Black, Lord Provost de la ciudad desde $1843^{33}$. Ejemplos como éste se encuentran en numerosos territorios -británicos, norteamericanos, cubanos, belgas, portugueses, etc.- en los que la masonería tuvo un peso considerable en su identidad cultural a lo largo del siglo XIX y principios del siglo XX.

El monumento fue concebido como si de una obra de arte total se tratara -en el sentido wagneriano del término-, pues poseía cualidades arquitectónicas, escultóricas referencias poéticas y literarias- y de ingeniería no vistas hasta la fecha, dado su elevada altura, más de 200 pies. En el diseño de Kemp, 64 hornacinas iban a ser destinadas para colocar esculturas que representaran a los personajes literarios y poéticos de Scott. En su inauguración, tan sólo 8 ocupaban su espacio. Otras 24 esculturas fueron incorporadas al monumento en 1871, año del centenario del

\footnotetext{
${ }^{30}$ Señalar que curiosamente, y a modo significativo, en la Caledonian Railway Company se creó una logia móvil entre sus propiedades, adscrita a la Gran Logia de Escocia, a la que pertenecían los ferroviarios y otro personal de la compañía.

${ }^{31}$ Desempeña este cargo de Preboste, título equivalente al de alcalde-mayor de la ciudad.

${ }^{32} \mathrm{http}: / /$ sites.scran.ac.uk/scottmon/pages/mon_construcion/cons_page2.htm. [consultado el 23 de febrero de 2009].

${ }^{33}$ GILBERT, William Matthews - Edinburgh in the Nineteenth Century. Edimburgo, 1901, p. 101.
} 
nacimiento del artista, finalizándose el conjunto con las 32 restantes en 1882. Esculturas representando a Jeannie Deans, The Last Minstrel, The Glee Maiden, Dandie Dinmont y Rob Roy eran insertas en los pináculos, arbotantes y hornacinas del monumento junto a 16 figuras en miniatura que representaban a notables poetas de Escocia. El prestigioso acuarelista escocés David Roberts (1796-1864), también francmasón desde $1815^{34}$, diseñó las vidrieras de la sala ubicada sobre el templete abovedado donde descansa la escultura monumental de Steel. Se trata de una sala noble, la única cerrada del recinto, sobre la que se levanta una especie de construcción híbrida entre campanario y cimborrio exento, que corona el propio monumento conmemorativo.

\section{La protección patrimonial de lo medieval y el empleo del neogótico en masonería}

Durante el siglo XIX, ya instaurado el Romanticismo en sentido cultural, los posicionamientos teóricos francmasónicos ante el Gótico comienzan a ser unánimes. En este sentido, la protección, el interés científico y mitológico por todo lo medieval llevó a los arquitectos, artistas y literatos masones a tomar conciencia de la necesidad de llevar a cabo una eficaz protección del patrimonio Gótico y Románico; éste último por ser el precedente directo de la espiritualidad simbólica gremial del medievo.

Focos importantes de la masonería británica como York o Edimburgo ${ }^{35}$ generaron un discurso patrimonial en torno a su pasado medieval, entrelazando mitos, leyendas, inspiraciones románticas, mientras restauraban o creaban un nuevo edificio gotizante. Las Constituciones de Anderson aludían ya, en la versión de 1738, a la importancia de la masonería en el Norte de Inglaterra, especialmente desde la perspectiva histórica operativa en la zona de Yorkshire. La tradición masónica del siglo XVIII entendía que la finalidad de la convocatoria que el Príncipe Edwin hace en el año 926 en York -en la

34 SIM, Katharine - David Roberts R.A., 1796-1864: a biography. Londres: Quarter Books, 1984, p. 24. ISBN: 0704323710.

${ }^{35}$ En Edimburgo se conserva un juramento masónico de 1669, por el que se juraba por Dios, por San Juan, por la Escuadra y el Compás. FERRER BENIMELI, José A. - La Masonería. Madrid: Alianza Editorial, 2005, p. 25. ISBN: 9788420647890. 
que congrega a todos los masones de la zona-, no era otra sino la de formar una Gran Logia bajo su protección como Gran Maestro ${ }^{36}$.

Los propios masones británicos, bien como miembros de la Orden o a título personal como comitentes, serán quienes comiencen a considerar primordial la protección patrimonial de toda la arquitectura sagrada románica y gótica, formando parte activa en la recuperación y restauración de importantes construcciones medievales, denostadas por la historiografía artística.

Significativas en este sentido son las actuaciones de las logias de Cheltenham (Inglaterra), que asistieron a las restauraciones del claustro de la Catedral de Gloucester (1896). Años más tarde, las mismas logias en 1900 ayudaron a la reedificación y construcción de la Capilla y claustro de Tewkesbury Abbey (Gloucestershire, Inglaterra) [7]; y en 1901, a instancias de algunos de sus miembros propiciaron la edificación del pórtico sur de St. Mary's Church así como el arreglo de su baptisterio, justificando su presencia por ser el templo medieval más antiguo de la población de Cheltenham ${ }^{37}$.

Los recuerdos gremiales obvios en la Orden del Gran Arquitecto del Universo propician en sus miembros un vuelco con las reconstrucciones de conventos, catedrales e iglesias góticas, así como la erección de iglesias anglicanas de nueva planta en toda Gran Bretaña, principalmente en Inglaterra y Escocia.

A través de The Incorporated Church Building Society desde 1818 hasta 1892, Inglaterra y Gales renovaron y construyeron numerosas parroquias y capillas con formas neogóticas principalmente ${ }^{38}$. En el norte de Inglaterra, dos de los arquitectos más

\footnotetext{
36 York era considerada por muchos a principios del siglo XX como una especie de Meca de la Masonería. CHEESMAN, W. N. - The Four Grand Lodges of the Eigteenth Century, a paper read before Leeds Installed Master`s Association $24^{\text {th }}$ of February of 1910-, and the Humber Installed Master`s Lodge, 2494. Hull, Leeds: Whiteheads \& Miller printers, 1910, pp. 18-19.

${ }^{37}$ BARNARD, L. W. - Cheltenham Masonic Hall. Its Building and History. Cheltenham: Cheltenham Masonic Hall, 1932, p. 24.

${ }^{38}$ Los fondos gráficos y documentales de The Incorporated Church Building Society se encuentran en la Biblioteca de Lambeth Palace (Inglaterra), con acceso a la investigación digitalizada en http://www.lambethpalacelibrary.org/content/icbs [consultado y analizado durante la estancia de Leeds Metroplitan University, 1 de agosto de 2009 - 31 de octubre de 2009, analizada su validez a 10 de febrero de 2013].
} 
renombrados del momento ${ }^{39}$, y al mismo tiempo masones activos en Leeds ${ }^{40}$, Robert Dennis Chantrell (1793-1872), discípulo de John Soane, y Thomas Taylor (1778-1826) participaron en este programa de regeneración anglicana. Para los diseños empleados buscaban proporciones áureas bajo pautas góticas -escocesas e inglesas, pero no puginianas-, conectando así las creencias gremiales de la Orden y las connotaciones simbólicas de la geometría del Templo de Jerusalén ${ }^{41}$. Dennis Chantrell será el encargado también de proyectar la parroquia matriz de Leeds, St. Peter, que tras la demolición en 1837 se convertiría en uno de los templos más importantes -en forma, ornato y dimensiones- de todo Yorkshire [9].

Mientras se llevaban a cabo las labores de derribo de la parroquia matriz de Leeds, en la antigua torre campanario se descubrieron piezas talladas, de una antigüedad superior a la datación del recinto. Eran materiales, datables entre el siglo IX y X, que el arquitecto masón acopió y analizó, descubriendo que formaban parte de una cruz premedieval, de tipo céltico, de los primeros vestigios cristianos de la ciudad. Así, compuso una cruz, llamada Leeds Cross [10], con varios fragmentos originales, y una vez terminada la ubicó en el jardín de su residencia. El arquitecto cuando cambiaba de domicilio, curiosamente también llevaba la cruz a su nuevo jardín ${ }^{42}$. Esta tipología de cruz será empleada en la arquitectura funeraria por los francmasones del Norte de Inglaterra desde mediados del siglo XIX, fecha en la que se encuentra la Leeds Cross.

La masonería británica participó activamente en la decoración, restauración y preparación de numerosos templos religiosos del reino, centrando sus esfuerzos en los monasterios medievales y capillas góticas, promoviendo campañas, cenas benéficas y comisiones para tal efecto. David Bryce (1803-1876), arquitecto masón, promotor del estilo neogótico escocés, quien había edificado la sede principal de la masonería en

\footnotetext{
${ }^{39}$ WEBSTER, Christopher - "The Architectural Profession in Leeds 1800-50: A Case-Study in Provincial Practice". In Architectural History. Londres. ISSN: 0066-622X.Vol. 38 (1995), pp. 176-191.

40 SCARTH, A. y BRIAN, C. A. - History of the Lodge of Fidelity. Leeds, 1894. A esta logia pertenecieron numerosos arquitectos durante el siglo XIX: Taylor, Chantrell, Nevis Compton, William Perkin, S. D. Martin y William Hill.

${ }^{41}$ Cfr. BAYARD, Jean-Pierre - La Symbolique du Temple. París: Éditions Maçonniques de France, 2002.

${ }^{42} \mathrm{http}: / /$ dnausers.d-n-a.net/leodis-leeds/cross.html [consultado el 15 de marzo de 2013].
} 
Edimburgo, la Logia de San Andrés $(1858)^{43}$, recibe el encargo de restaurar Rosslyn Chapel $^{44}$ (1860-1861), capilla paradigmática que ya conocía no sólo como reputado masón sino como trabajador previo en reparaciones puntuales efectuadas en $1837^{45}$.

En esta última intervención del recinto sacro, el espacio adquiere nuevos elementos que potencian el discurso masónico establecido a lo largo de siglos por la familia Saint Clair -en sentido especulativo desde 1736-, cuestión que por otro lado hace en ocasiones difícil verificar cuáles son las piezas y capiteles adoptados en el siglo XIX -ángeles, bestiarios, etc. $-{ }^{46}[11]$. Las obras concluyen en abril de 1862 , fecha en la que se bendice la Capilla.

Este tipo de contratos profesionales, entre comitentes y arquitectos masones, se enmarcan dentro del lógico corporativismo -bien entendido- existente entre personas de un mismo ámbito y logia. Debe ser señalado que la familia Saint Clair había tenido un protagonismo histórico en la creación de la Gran Logia de Escocia en 1736, siendo William St. Clair elegido como primer Gran Maestre de la misma. Descendientes suyos como el General Sir James St. Clair Erskine of Rosslyn, también Gran Maestre de Escocia (1810-1811), habían propiciado restauraciones puntuales ayudados por los francmasones de la Gran Logia escocesa ${ }^{47}$.

No sólo las restauraciones medievales interesaban a los masones británicos. William $\mathrm{H}$. Stacey, reconocido erudito masón de Sheffield, señalaba en 1893, la importancia de consagrar nuevos templos, afirmando que para un masón no hay nada más importante

\footnotetext{
${ }^{43}$ Reemplazada por la actual en 1911. LAUREIS, William Alexander - The history of freemasonry and the Grand lodge of Scotland. Escocia: Seton \& Mackenzie, 1859, p. 318.

${ }^{44}$ Cfr. BRITTON, John - "An Essay Towards an History and description of Roslin Chapel, Scotland". In The Architectural Antiquities of Great Britain. Londres. Vol. II (1812), pp. 47-56. Para las conexiones de la capilla con la francmasonería escocesa cfr. WALLACE-MURPHY, Tim - The Templar Legacy and the Masonic Inheritance within Rosslyn Chapel. Roslin: Friends of Rosslyn, 1995. ISBN: 978-0952149316; BRYDON, Robert - Rosslyn. A History of The Guilds, The Masons and The Rosy Cross. Escocia: Rosslyn Chapel Trust, 1994. ISBN. 978-0952149330; KNIGHT, Christopher y LOMAS, Robert - The Hiram Key. Pharaons, Freemasons and the Discovery of the Secret Scrolls of Jesus. Londres: Arrow Books, 1996. ISBN: 978-0099699415; WALLACE-MURPHY, Tim y HOPKINS, Marilyn - Rosslyn. Guardian of the Secrets of the Holy Grail. Shaftesbury: Element Books Limited, 1999. ISBN: 9781862047426.

${ }^{45} \mathrm{http}: / /$ www.scottisharchitects.org.uk/architect_full.php?id=100014 [consultado el 20 de abril de 2009].

46 Determinadas formas de la cripta y la propia capilla parecen estar en consonancia con los gustos victorianos, incorporando arbitrariamente al edificio nuevos ángeles prerrafaelitas junto a otros neogóticos.

${ }^{47}$ BRYDON, Robert - op. cit.
} 
que la ceremonia de colocación de la primera piedra de un edificio religioso -por aquellas fechas normalmente construido como neogótico-- Sugería así que este acto simbólico revitalizaba las palabras de la Sagrada Escritura:

Las doctrinas, reglas y requerimientos de la Masonería inculcan orden, moralidad, afecto social, beneficencia y religión. Por ello, supone un regocijo la erección de templos donde las sublimes verdades y los puros preceptos de la Sagrada Escritura tan elocuentemente asumen la propagación y el ejercicio de estas virtudes como esenciales para nuestra felicidad en este mundo y el venidero ¿Quién puede quedarse indiferente al espectáculo que presenta hoy el acto de ejecutar los deberes [en sentido masónico] o las esperanzas y las perspectivas que inspira? ${ }^{48}$.

De esta realidad, es muy habitual encontrarse con vidrieras conmemorativas con alusiones gremiales a la construcción del templo de Salomón en templos anglicanos y escoceses, como la propia iglesia de St. Edmund en Falinge, perteneciente al municipio de Rochdale (Inglaterra) [8], construida por James Medland Taylor en 1875 para preservar la memoria de los padres del masón y filántropo Albert Hudson Royd. Se trata de una obra paradigmática de nueva planta que recrea por parte de un comitente masón, fundador de escuelas y logias masónicas, donde el conjunto resume todos los elementos propios del sentir medievalista, aflorado en la masonería de Gran Bretaña desde mediados del siglo XIX. Estos elementos no deben ser obviados en el análisis estético de la historia del arte y la cultura europea, debido a que no solo explican claves y condicionantes sino además la apropiación de un gusto y determinados estilos, con un carácter totalmente supranacional y metalenguajes que marcan hitos simbólicos contemporáneos.

${ }^{48}$ STACEY, William H. - History of the Royal Brunswick Lodge. 1793-1893. Sheffield: Royal Brunswick Lodge, 1893, p. 46. Traducción del autor. 


\section{Conclusiones:}

La importancia de la masonería en la cultura británica contemporánea y en los postulados del anglicanismo es significativa a la hora de entender el estrecho vínculo de la Orden del Gran Arquitecto del Universo con la restauración patrimonial de lo medieval. Su implicación directa en restauraciones de viejos monasterios y catedrales, así como en la construcción de numersos templos neogóticos en Gran Bretaña, principalmente Inglaterra y Escocia, ponen de manifiesto el peso del sentido simbólico en esta asociación filosófica. Esta circunstancia ha permitido una estrecha conjunción simbólica y artística en la revitalización estética del neogótico como estilo imperante. De forma activa, la masonería como conjunto asociativo -y red corporativa de patrocinadores- así como arquitectos y artistas masones actúan deliberadamente.

Comitentes o ejecutantes, los masones británicos imprimen una singuar carga simbólica asociada a esta recuperación medieval, que viene reforzada desde la preconización del romanticismo británico hasta mediados del siglo XX. En algunos casos como la Escocia de Walter Scott, la reivindicación se torna identidad nacional a través del neogótico escocés - del arquitecto masón David Bryce- y se vincula directamente a la estética masónica por el respaldo de clanes familiares asociados al antiguo colectivo gremial. Esta atemporalidad de la colectividad británica ha permitido, sin lugar a dudas, un profundo enraizamiento cultural de "lo masónico" en el desarrollo patrimonial del mundo medieval, cuestión que no debe ser obviada a la hora de historiar la difusión y divulgación histórica contemporánea del pasado del país atlántico. 


\section{Imágenes:}

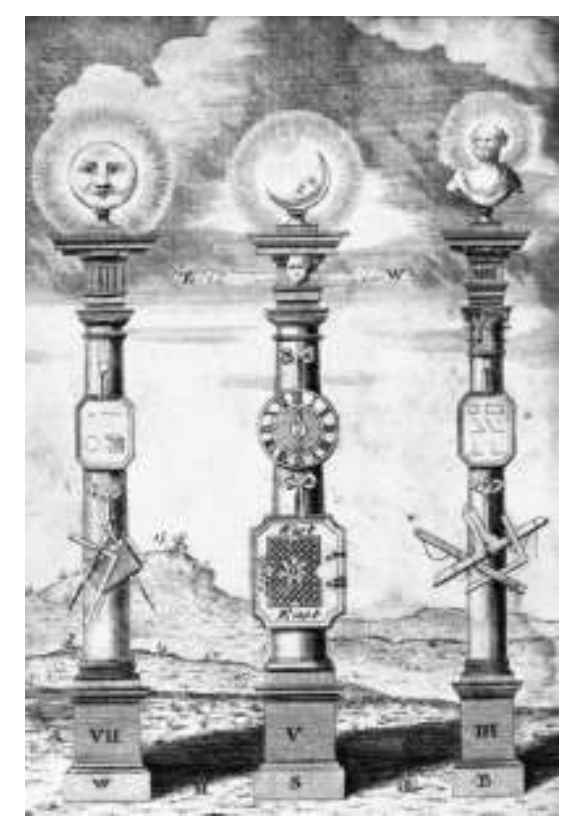

[1] Batty Langley. Obra grabada en The Builder's jewel (1741). En este grabado pueden apreciarse las tres luces, columnas masónicas, con el Sol y la Luna y Pitágoras sobre sus capiteles.

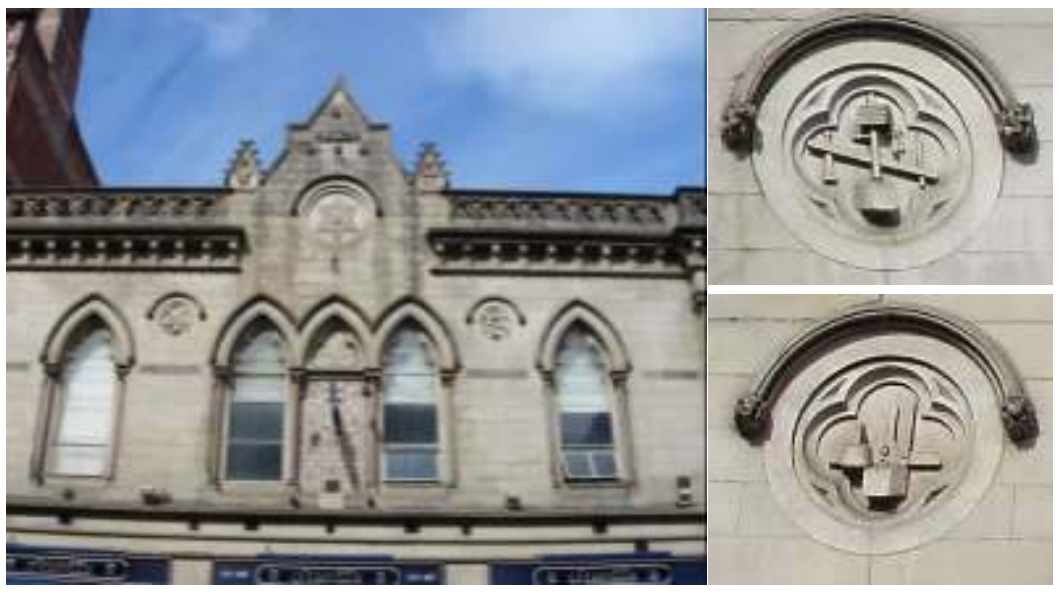

[2] Templo masónico y detalles de la fachada de Philanthropic Lodge, Leeds (1865). Obra de Perkin \& Sons, responde a la utilización del neogótico como elemento distintivo de la Orden. 


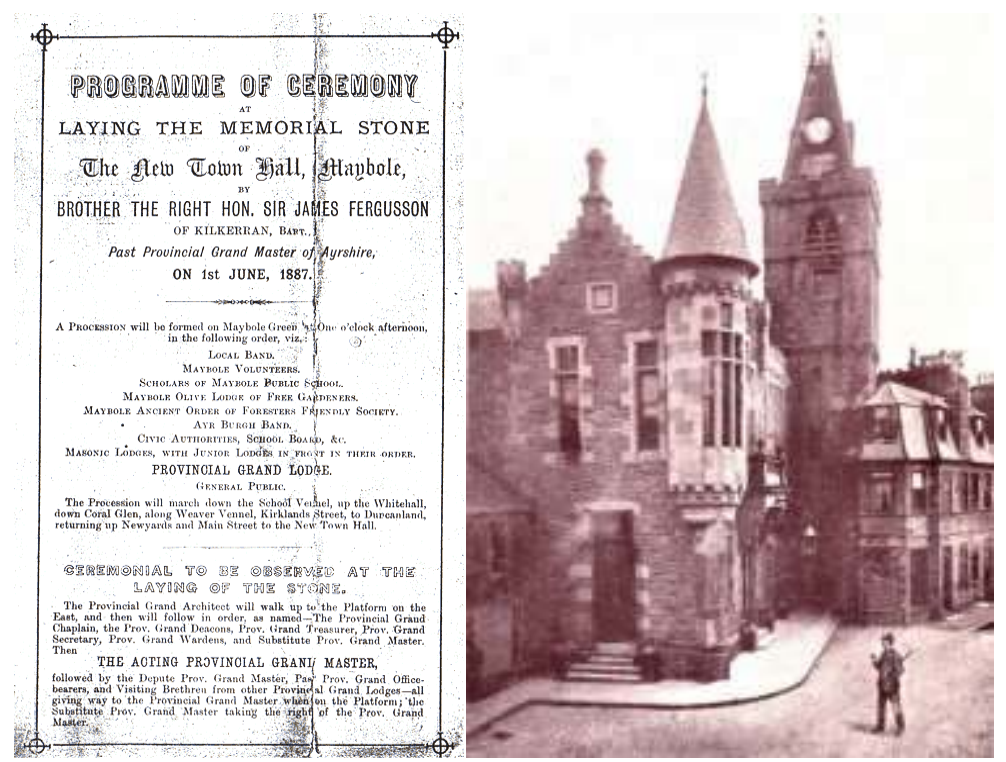

[3] Cartel de la Ceremonia de colocación de la primera piedra del Ayuntamiento de Maybole, con un programa eminentemente masónico, en el que participó el anterior Gran Maestre de la Provincia de Ayrshire, Sir James Fergusson (1887). Imagen derecha: Ayuntamiento de Maybole, Escocia.

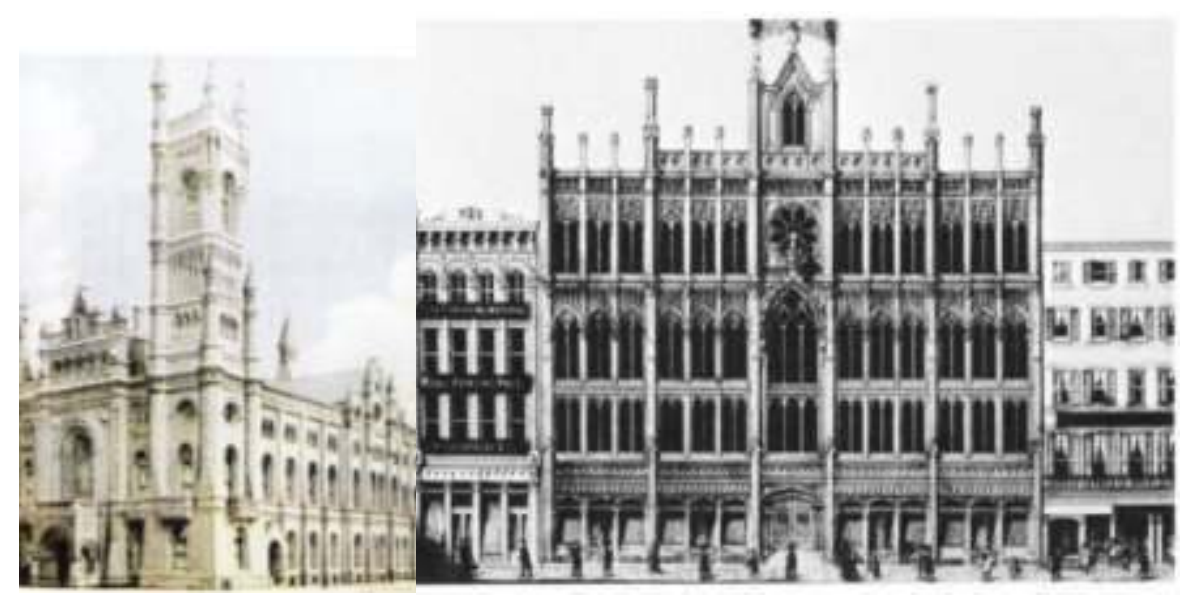

[4] Dos templos masónicos en Estados Unidos: Gran Logia de Filadelfia (izquierda), obra del arquitecto J. H. Widrin (1868) y el Masonic Temple. Obra de Sloan y Stewart. Filadelfia (1853-1855) (derecha). 


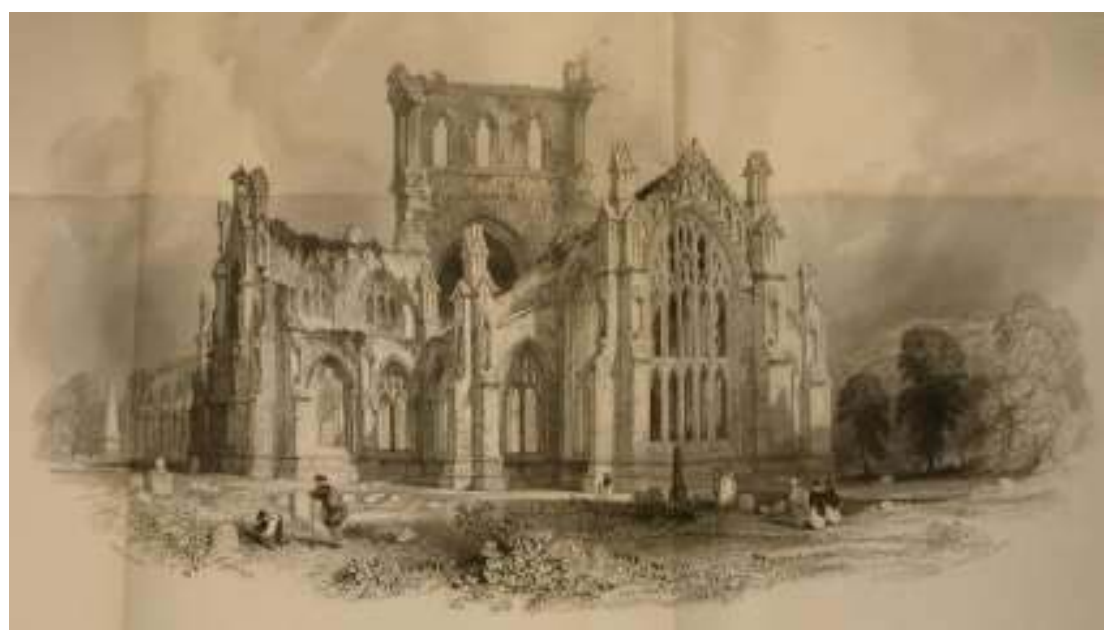

[5] Melrose Abbey, Escocia en la obra de LEWIS, Samuel: A topographical dictionary of Scotland. Londres, 1846. Esta paradigmática abadía en ruinas donde trabajó el mítico maestro masón John Morvo se convierte en centro de peregrinación ilustrada. Elemento inspirador para los francmasones Walter Scott, Geroge M. Kemp y David Roberts, las ruinas escocesas se convierten en una de las primeras revalorizaciones estéticas del medievo en sentido masónico. Colección victoriana de la Universidad de Glasgow.
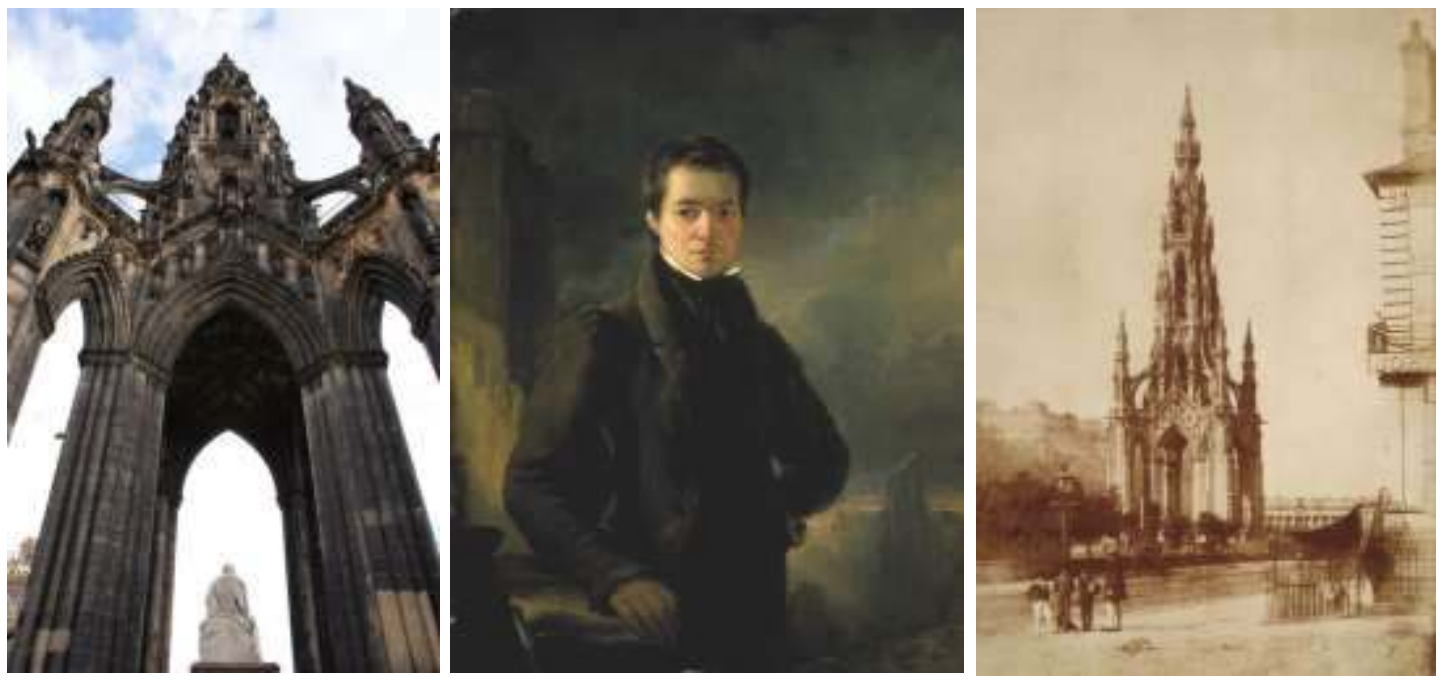

[6] Vista del Monumento de Sir Walter Scott (Edimburgo) y estado de la obra en 1845, en el que la escultura de Walter Scott no ha sido incorporada al monumento (imagen derecha). La maginificencia constructiva gótica significó una ampliación estética Retrato de William Meikle Kemp (imagen central), obra de su cuñado William Bonnar (c. 1844). National Galleries, Escocia. 


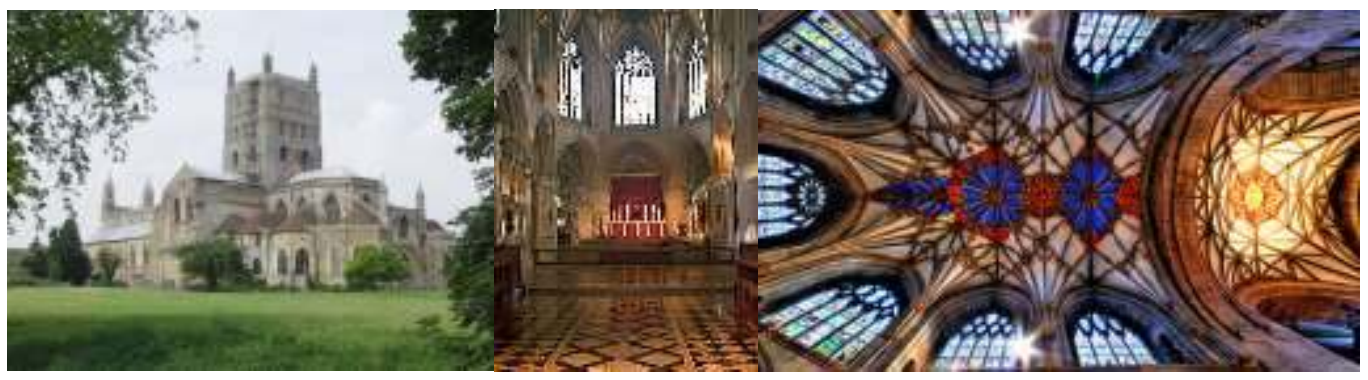

[7] Tewkesbury Abbey, Gloucestershire, Inglaterra. La francmasonería de finales del siglo XIX y del siglo XX restaura espacios monásticos como símbolos del pasado medieval. En concreto, las logias de Chetelham en 1910 rehabilitaron el claustro y la capilla. En la restauración se refuerza el ajedrezado simbólico, algo que sucederá en numerosas iglesias construidas o restauradas por francmasones, donde el carácter estético de esta solería adquiere un doble valor al habitual.

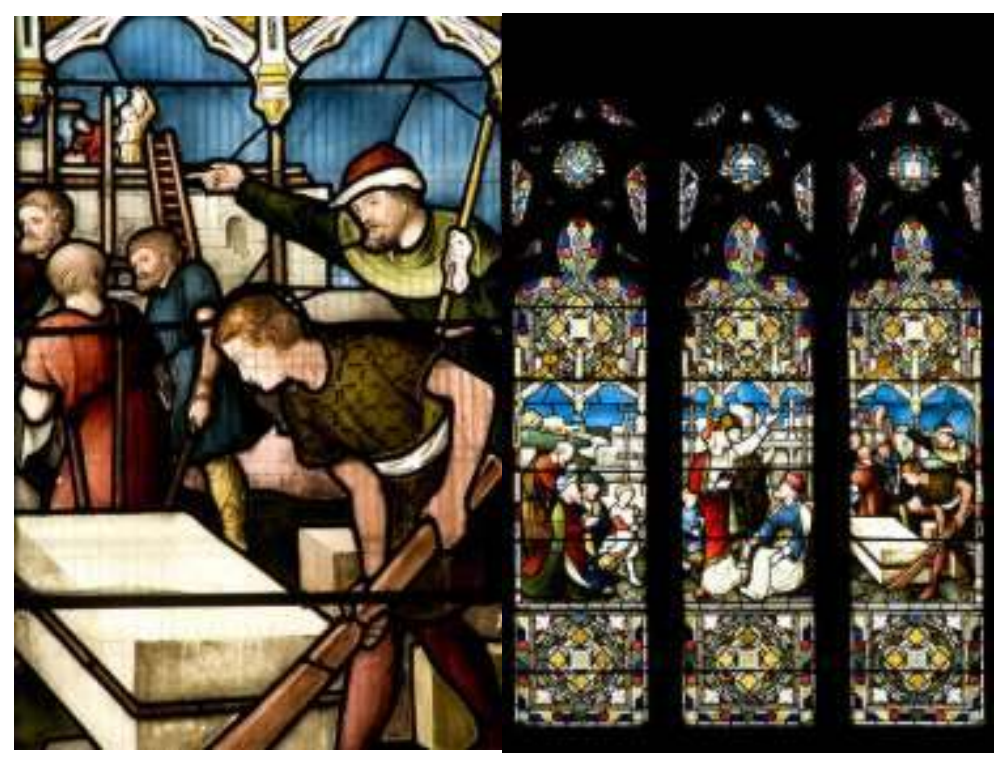

[8] Detalle de masón operativo de la vidriera en la Leyenda del Templo de Jerusalén (imagen derecha). St. Edmund, Falinge. Rochdale, Inglaterra. Los personajes están caracterizados como masones operativos del Medievo, junto a Salomón, los sacerdotes e Hiram. La iglesia fue fundada bajo una ceremonia masónica y los símbolos alusivos a la Orden están presentes en ella. 


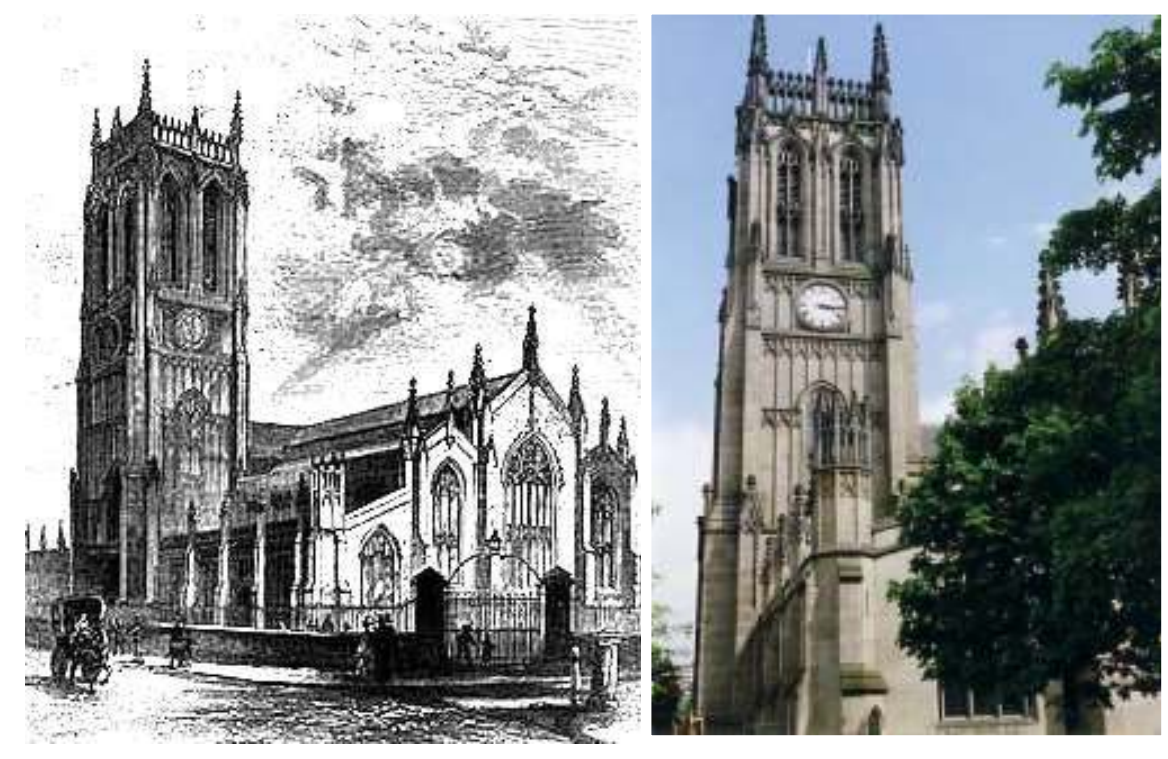

[9] Iglesia de St. Peter, Leeds. R. D. Chantrell (1837-1841). Es la parroquia matriz anglicana de la ciudad por lo que todo el simbolismo de la Orden es manifestado en ella. En las labores de reconstrucción y ampliación se encontraron con los fragmentos milenarios de varias cruces recompuestas como Leeds Cross.
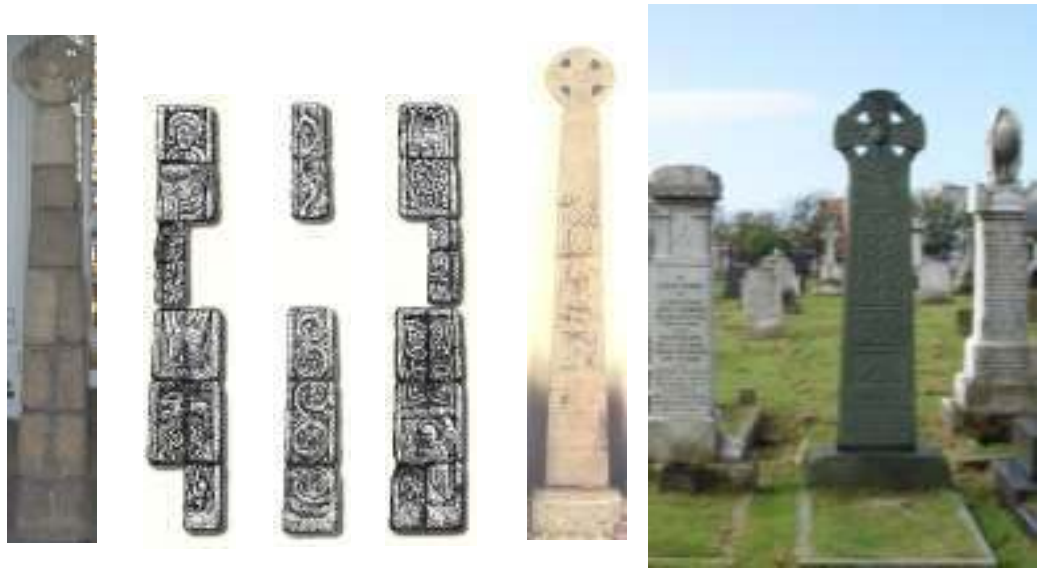

[10] Diferentes aspectos de la Leeds Cross. St. Peter's Church, parroquia matriz anglicana de Leeds. Es construida por Chantrell quien en el momento de su reforma encuentra los fragmentos de la cruz. Tumba de granito verde con cruz celta de la familia Crewe en Blackpool (1924). Imita a la Leeds Cross y a sus variantes encontradas en el siglo XIX. Los masones insertan en ella además símbolos de la 
Orden, como el Teorema de Pitágoras, joya de Ex-Venerable Maestro (imagen derecha).

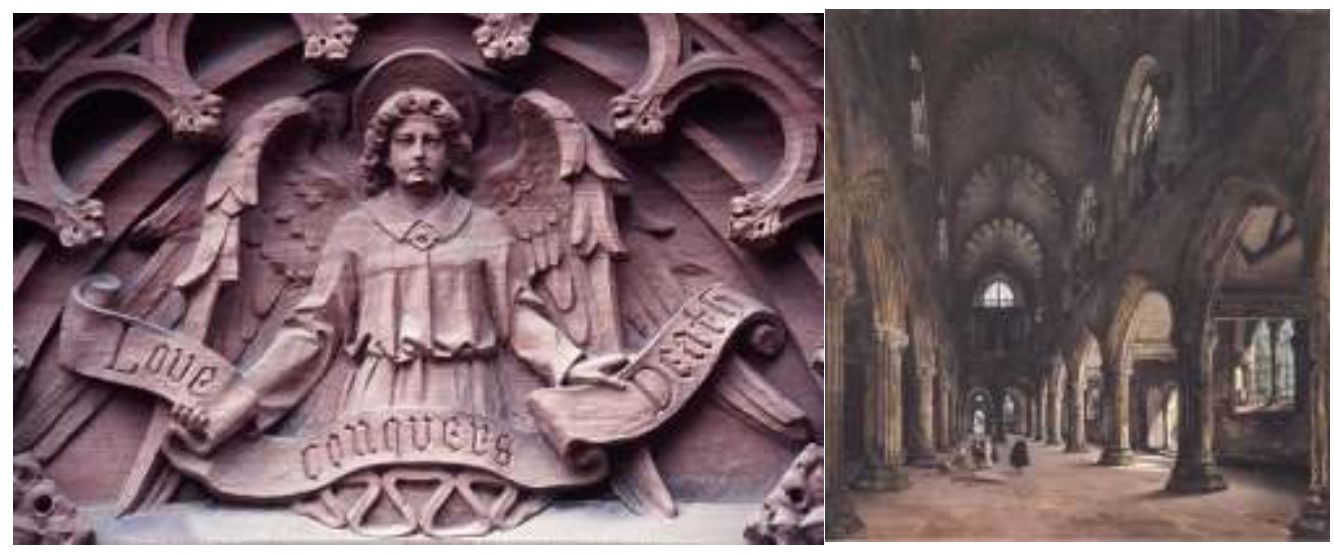

[11] Soluciones de Rosslyn Chapel realizadas en 1861 por David Bryce, arquitecto francmasón. En estas se aprecian determinadas fórmulas neogóticas, con elementos deudores del prerrafaelismo que se han asociado para potenciar la percepción masónica del conjunto dentro de los nuevos aires románticos de la Orden en Escocia, siguiendo así la larga tradición previa incluso a Walter Scott. Louis Daguerre, Interior de Rosslyn Chapel. FRAM, Musées du Haute Normandie (imagen derecha). Numerosos masones artistas y fotógrafos del siglo XIX se sintieron atraídos por el mito de Rosslyn tras la evocación poética de Walter Scott. La Orden en Escocia cuyos Gran Maestre habían sido normalmente miembros de la familia St. Clair, imprimieron el carácter francmasónico en su patrimonio medieval haciendo veladas masónicas en el conjunto y realizando obras benéficas para la restauración de la capilla. 
La revalorización del medievo en la estética masónica: Inglaterra y Escocia (siglos XIX y XX) • David Martín López

\section{COMO CITAR ESTE ARTIGO}

\section{Referência electrónica:}

MARTÍN LÓPEZ, David - "La revalorización del medievo en la estética masónica: Inglaterra y Escocia (siglos XIX y XX)". Medievalista [Em linha]. N¹5, (Janeiro Junho 2014). [Consultado dd.mm.aaaa]. Disponível em http://www2.fcsh.unl.pt/iem/medievalista/MEDIEVALISTA15/lopez1505.html.

ISSN 1646-740X.

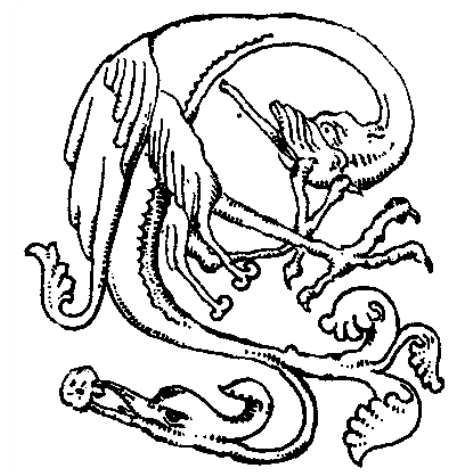

